\title{
PALEOGRAPHY AND ORTHOGRAPHY OF HANKENSTEIN CODEX
}

\author{
Anna P. Khmelevskaya ${ }^{1}$ \\ Oleg F. Zholobov ${ }^{2}$ \\ Georgiy A. Molkov ${ }^{3}$
}

\begin{abstract}
Hankenstein Code (Vienna Octoix) is the collection of liturgical texts dating by the XII-XIII centuries or by the beginning of the XIIIth century. Since 1804, the general descriptions of the collection appear in the works by I.A. Ganke von Gankenstein, J. Dobrovsky,
\end{abstract} S. Smal-Stotsky, A. Sobolevsky, Yu. Shevelev, G. Birkfellner. Nowadays, there is no satisfactory analysis of the Code text at all levels, including graphic one. In order to study the spelling and the paleographic features of the manuscript, the main text, the inscriptions and the drawings on the fields, ornaments, the material for writing, the present state of the manuscript and its parts were described. We found that the text was written by two scribes, characterized the manner of writing each of them, determined the differences in the graphics and spelling (different use of the letters я, 1, 8 and o). A large number of external letters was noted and 7 basic traits of the title were described, 3 types of superscripts and 6 types of inline signs were fixed, their graphic and functional features were described. For the first time corrections and the entries were described on the margins of the manuscript. The examples found in the text of the letters э, е and и, в and oy proved the hypothesis of the southwestern origin of the monument.

Keywords: paleography,

Paleoslavistics, spelling, GalicianVolhynian manuscripts, Gankenstein code, Vienna octoides, ancient Russian monuments of the 12th-13th centuries.

\section{Introduction}

1 Kazan Federal University, Leo Tolstoy Institute of Philology and Intercultural Communication.hmelevskayann@mail.ru.

2 Kazan Federal University, Leo Tolstoy Institute of Philology and Intercultural Communication. hmelevskayann@mail.ru.

${ }^{3}$ Russian Academy of Sciences, Institute for Linguistic Studies. 
Hankenstein Code (Birkfellners

cat. No. II / 141, Vienna, Austrian National Library, cod. Slav. 37) is the Galician-Volyn manuscript, the main text of which is the collection of liturgical texts. The researchers refer it to the turn of the 12th-13th centuries; it is supplemented by the records on the margins at the turn of the 13th-14th centuries and the first half of the XVth century [1].

The Code received its first and official name by the surname of its first historically famous owner - I.A. Ganke von Gankenstein (1751-1806), the librarian from Olomouc, an amateur linguist. He became the first researcher of the Code text, but many of his statements were erroneous. For example, Gankenstein argued that the main text of the octoic was written in the VIIIth century and that the book is the oldest monument of Slavonic writing [2], which is a mistake, of course.

Hankeshtein's assumptions were challenged in the works by $\mathrm{J}$. Dobrovsky and N.M. Karamzin [3]. At various times, various attempts have been made to describe the manuscript since the XVIIIth century (K. Kisilevsky, S. Smal-Stotsky, A.
Sobolevsky, Yu. Shevelev, G. Birkfellner). The latter indicate that the book comes from the Galician-Volyn region [4]. The part of the octoic was published by G. Birkfellner [5, 6].

Nowadays, there is no paleographic description of the Code, which would provide a complete picture of the paleographic and spelling peculiarity of the manuscript. Moreover, the relevance of modern studies of graphics and spelling of handwritten monuments is that they allow us to specify the dating suggested by the catalogs (see the description of the Pogodin Gospel letter features [7]).

\section{Methods}

The object of our study was the book itself and its main text, which dates back to the beginning of the 13th century.

Our work is the part of a comprehensive analysis of the Code language features and it is carried out as the part of a joint project with the colleagues from the Institute of Slavic Studies at the University of Vienna "The preparation of Internet publication and the study of the Vienna octoi of XIIXIIIth centuries." 
The study was carried out using a digital photocopy of the manuscript provided by Austrian colleagues. Nowadays, the work for the preparation of an online publication has begun already; the publication is performed on the portal "Manuscript" (http://manuscripts.ru), where you can see the part of the text.

\section{Results and discussion}

The manuscript of the Hankenstein Code has the following dimensions: 279 by $205 \mathrm{~mm}$. In fact, the book contains 290 sheets, not 292 ones, as some previous researchers have pointed out [3], since pagination is lost on the page 75 . The oldest part of the Code occupies 288 sheets, starting with p. 3., sh. 1 and 1.2 are filled with Sunday stichera for 8 voices written at a later time (first half of the 15th century) [3].

Binding. According to Hankenstein's description, the cover of the book was a wooden board, covered with a thin sheepskin skin. Once all four corners of the cover were decorated with corners of brass, but there was only one corner by the time of the manuscript acquisition by Gankenstein. As the researcher notes, it is obvious that the other three corners were lost due to the frequent use of the book, and were not torn down deliberately [2].

According to the description from the catalog of the Austrian National Library [8] the leather on the boards is embossed.

Manuscript content. The main text has the following content:

sh. 1-154: Six-day official;

sh. 155-238: Pillar apracos;

sh. 238-240: Sunday contakion for eight tones;

sh. 241-290: The Common Menaion.

Material and its features. The sheets of the book are made of parchment; their condition as a whole can be characterized as satisfactory. As many manuscripts, it has cuts, holes or rubbing; most of these defects existed on the parchment initially - the scribe bypasses these places by the side during work.

\section{Imperfections of the parchment:}

a) page breaks/cuts. Some of the breaks are sewn with threads (sh. 28, 30, 
etc.), the text is written over the seam (sh. 28, 88, etc.).

b) Torn off edges (Fig. 9, 17, etc.).

c) An inhomogeneous sheet density.

d) The holes from wax or a writing instrument.

Pagination. The Codex sheets are numbered with Arabic numerals on the front side of each sheet in the center of the upper margin. After the sheet 75 pagination is lost, the sheet 78 follows after instead of sheet 76 .

Every tenth sheet, starting with sh. 20 , has an additional pagination made at a later time. Numbers are written by pencil with large numbers in the upper right corner of the sheet, less often in the left field (sh. 80, 160-230, 250), once in the center at the top (1. 140). The numbers are absent on sh. 240, 260, 270 , 290.

Line. Each page of the manuscript is scattered, line traces with a sharp object are present. The text of the manuscript is written by one 16-line column.

Ink. The main text of the Code is written in black ink. The headings, initials, the initial words of the irromos and the introduction are made by cinnabar (or written in black, and then lined in red: sh. 77 , turn 116, 118, etc.).

Ornaments. The ornaments in the Code are presented only by the introduction before the text of the octoic and by the initials.

The introduction on sh. 1 is a rectangular shaped frame filled with the ornamentation of a plant motif and interlacing. The heads of monsters with open mouths from the left and right upper corners are beyond the frame. The transition to the teratological style is obvious, although the characteristic denial of the geometric principle and asymmetry are not observed [9].

The scribe I has mostly small initials (1.5-2 lines in height), without any ornaments or with a minimum of ornaments (crossbeams, a minor floral ornament, a pattern inside the letter). The initials of the second scribe are larger (the height makes 4-5 lines) and more elegant (interlacing and plant motifs). Turilov writes that the initials also have teratological style [3], but there are few such initials in the entire manuscript. Zoomorphic elements and complex plexuses characteristic for teratological style and making the letter difficult to 
recognize, were met in the manuscript only a few times, for example, on the sheet 160 .

There are no miniatures in the manuscript. Sheet 130 has a field decoration - a cinnabar flower.

Handwriting. The text of the octoic is written in small charter by two scribes. Voskresensky still has the indication of two different handwritings presence, by one of which "not so large" the part of the text is written on sh. 203240 [10].

1) The first handwriting is presented at the beginning (sh. 1-202) and at the end (sh. 241-290) of the book; it is quite large, although its size varies several times. The letters are narrow: c, е, о are like), the letter ю looks like и. The upper parts of the letters в, ж, к, ч are smaller than the lower ones. The features of other letter writing:

ט̂. Mirrored, used only in numerical value.

Z. The lower part of the letter does not lie on the line, but is inclined. The "tail" of the letter is short one.

$H$. The crossbar is often located above the middle of the letter, parallel to a line.
$\mathrm{K}$. The left and the right part of the letter are written separately.

M. The loop lines retain roundness, but its lower part is sharpened. Vertical bars are not parallel to each other, their upper ends are closer than the lower ones.

$\mathrm{N}$. Often with a bar parallel to the line, which makes it close to $и$, however, $\mathrm{H}$ crossbar rarely rises above the middle of the letter.

Round H. Sometimes it is crossed out by a longitudinal line or is decorated with a dot inside the letter.

$H$. The ends of the letter are long. The lines are curved; they intersect much higher than the middle of a line.

Q. The cup is narrow, pointed one. The sites at the ends are absent.

\}Y. The combination of the letters ъ и).

. The mast of the letter is high, but it does not go outside a line.

!. The connecting line is raised.

Ë. The connecting line is in the middle of a line.

ó. A round one, with the lowered middle. As a rule, a comma is placed above 8 , but there are exceptions in the form of spelling with two points (p. 3, 157). 
ý. It is the letter o with a "tick" at the top.

y. It has a long "tail" in the meaning of the sound [и] and in the composition oy. In the meaning of sound [в] it is written as -.

2) The handwriting of the scribe II has a stable, medium-sized and recognizable style. The letters differ by a large number of serifs, thus the handwriting looks more accurate and clear.

A. A sharp loop.

E. A narrow one, like the first scribe, but the middle line is clearly drawn, it goes beyond the letter often. $\ddot{\mathrm{E}}$ is written similarly.

$\mathrm{J}$. The upper cup is smaller than the bottom one, like the first scribe.

Z. The "tail" is short, it lies on the line, turns to the right.

I. The crossbar is high, parallel to the line.

$\mathrm{K}$. The left and the right parts are written separately.

M. The loop is rounded, sometimes it drops below the line. Vertical lines are not parallel to each other.

N. The crossbar is always inclined.
Q. The cup is wide and round one, there are serifs at the ends.

!. The connecting line is located in the middle, it is decorated with dots often.

$\sim$. The mast is low, it extends beyond the crossbar barely.

$y$. The bottom end of the letter is short one.

ó. Rounded parts, but the middle is low, it almost lies on a line, the ends tend to each other.

F. As a rule, these are two lines: a circle crossed by a vertical line. But sometimes there is a more complex inscription, similar to the modern one. Sometimes a mast is decorated with a dot.

v. It looks like an unfinished eight.

Title. The manuscript of the Code has diverse titles by writing and by character.

1. The title is round, "arched" one. It is used in the main text only over the remote д. The exception is the top of abbreviations in a header.

2. The title in the form of a "gable roof". Also in the abbreviated words above the remote д. 
3. A horizontal line with the ends down.

It is used for abbreviated words and letters in numerical value.

4. A straight horizontal line.

5. A horizontal line with the right end down.

6. A horizontal line with the left end down.

7. The combination of a title with the lowered ends and the letter д.

The titles of the scribe II are always decorated with a dot in the center.

Remote letters. The abbreviations with remote letters is the phenomenon which is quite frequent in the Code. As a rule, remote letters are met in the most ancient charter, in "sacred words" [9], however they are also often in Code lexemes that do not have sacral semantics. Not only letters in abbreviated words can be remote, but also the letters missed by a scribe by mistake: сво(е)ю 18th turn, тьлень(н) 5 th turn, etc.

\section{Superscript signs}

- Dot. It was put over specific letters: ), $\mathrm{b}$ and $\mathrm{b}$, over the letter written by mistake, and instead of the remote $\mathrm{c}$. In general, the dots over letters in a text are not uncommon, but their location, is usually random.
- Two points. They are placed above ) and sometimes above 8 .

- A comma. It is placed over 8 .

Inline signs

- A dot. It is put at the end and in the middle of a paragraph, apparently, in place of pauses. It is located on the line after the word.

- Four points that form the rhombus is a display mark indicating the end of a paragraph. It is located on a line, less often in the middle.

- Three points located in a row make a highlight mark, following fourpoint line. It is located on a line.

- The cross indicates that a letter, a syllable, a word or a passage is missed in a particular place. Thus, the cross over a letter is similar to a modern footnote it is accompanied by the same cross on the margins of a sheet, under which the correction is indicated (for example, sh. 183).

- Colon. Rarely replaces an inline point. For example, on turn 112 and 113 all punctuation marks are replaced by colons.

- A sign that looks like a crescent with a dot inside. It is written on a left field before a title. 
Field notes. Most of the records are made with a sharp instrument by a large charter, some of them are almost indistinguishable: sh. 19, 30, etc. Those records that are deciphered can be divided into the following groups: letters, including the letters in alphabetic order $(66,130$, etc. $)$; the records between the lines (161); syllables, words, word combunations and phrases: здоровъ полко 271, the records on sh. 22, turn 148 , etc. A postscript by the half-charter on the sh. 151 deserves a separate attention: ги=ну моему пану даш...у probably this is the record of the scribe or the owner of the book, who was going to give it to a certain "Pan Dashko" (most likely, this name is specified by a halferased inscription).

Errors and corrections. As a rule, mistakes are random ones; it can be a miss of a letter (прэстоуплэнимь instead of прэстоуплэниёмь, 8 turn) or the writing of one letter instead of the other one (своюю 8 instead of своёю); the change of letters in a syllable (черлвена 10; доднеже 192); the use of a digraph instead of Izhitsa (коупарисе, 18th turn).

Corrections on the margins. A cross is put above a miss (an error) (sh.
92, 93, 93 turn) or a dot, a correct/a missing text element is displayed on a margin.

Correction of letters in a text. Often copyists correct their own mistakes in a text, adding some missing lines to a desired letter where possible. Thus, a frequent correction is experienced by ь - в ь (sh. 4, 28), о- в ъ (29 turn, 36), а - в о (17), о - в а (21).

The corrections above a line. A missing letter or a syllable is inscribed above a mising place: (с)илоу 4 turn, съмэ(ше)ниё 10 turn.

\section{Features of spelling}

o, 8 and 7. The scribe I has the letter 8 on the first 53 pages at the beginning of the words, less often the round o. Starting with the sheet 54, the letters o and 8 appear equally often at the beginning of a word; in the middle of a word, in most cases 8 is written only after a vowel.

The second scribe keeps a clear distinction: an omega with a dot above is written at the beginning of a word, and more rarely a round $\mathrm{o}$; o or omega is written in the middle of words (after the vowels) - with or without a point. 
oУ, oy, y. Both scribes use a combination oy. to provide the sound [y]. $v$ is spelled seldom and, as a rule, where a line should end with a syllable -oy to save space. $\mathrm{u}$ is written very seldom: ськрушиль 29, умьрщвенаго 33, суботэ 173 turn and etc.

y. Izhitsa could serve as the designation for different sounds in different positions. Before the consonant, izhitsa denotes the sound [и]. There are few words of this kind actually: муроносица 39, муромъ 51, купарисъ 121, etc. Before the vowel y denotes the sound [в]: еужины 74 turn, eya 154, 157, 160 turn, etc.; In this case, the tip of the letter becomes shorter, it is written as -.

e, ë. Both scribes write the letter If at the beginning of a word and after vowels, e is written after the soft and hard consonants.

я, 1. The writing of $я, 1$ less consistent. In the handwriting of the scribe $\mathrm{I} я$ is written after soft consonants and ц, 1 - after the vowels and at the beginning of a word. In the part written by the scribe II, 1 is written not only after the vowels and at the beginning of a word, but also after soft consonants and ц; я is written after soft consonants,
325

rarely after ц. A is written most often after soft hissing in both handwriting.

And the decimal is written without a period in most cases; there are the spelling with a point (often in words) нъ 27, 30, etc., )оана 158 turn, etc.) and less often with two points (4 turn, 117 turn, etc.). The scribe I has the additions of ), with or without a point: на)древэ 77 turn, кра)сотоу 110, рважи1)ми 123 turn.

The combinations of the sounds [cч] at the junction of a preposition / a prefix and a root on a letter are transmitted standardly with the letter щ: ищисты1 20, бещисльною 39, ищресель 53, ищрева 58 turn, ищертога 89 turn, etc.

There is the addition of д between 3 and p: въздрадоваша же ся 188 turn, раздрэшати 250 turn, издрядьно 256 turn, etc. The standard spelling is also a missing c before c, ц, ш: ицэлэхомъ 8 , бесэмене 266 , ишьль ёси 80 etc.

The spelling features caused by the place of the monument creation include the following ones:

The mixing of э, е, ), и. The mixing of the letters e, e, и, ) characteristic for the Galician-Volhynian 
texts is presented mainly in the postscript fields of the late 13th-14th centuries; In the main text such examples are rare ones (for example, сп=сетеля 113 turn, where an error can be presented).

The exception is in the writing of the word "Ирмос". More than 90\% of spellings begin with the letter ). However, there are the variants beginning with и $(6,11,15$ turn, 146 turn, etc.), e (1, 2, 12 turn), ë (7, 11 turn, 14 turn, 16 turn, 17, 17 turn, 18 turn, 19).

The mixing of $\mathrm{B}$ and oy. Another south-western feature is the indistinction of the sounds $[\mathrm{B}]$ and $[\mathrm{y}]$ by scribes, expressed in a mixture of letters в and oy: и оу ёдиненъ пламень 47, и оу ёдиноу црквь 47, оутории 108 , воудици 56 turn instead of оудици).

The combination жч characteristic for the Galician-Volyn region takes place in the manuscript there as the result of $*_{\mathrm{zg}}$ ижченоуть palatalization, 176 turn. (see the description of the Galician-Volyn manuscript of the second half of the 13th century [11]).

\section{Conclusions}

The manuscript of the Vienna octoiha was written by two scribes: this

is proved by the fundamental differences in spelling: the use of small юca, the distinction between $я$ and $1, \mathrm{o}$ and 8 .

The analysis of the paleographic features of the manuscript confirms the dating given by the majority of researchers - the beginning of the 13th century. This is evidenced, for example, by the analysis of ornaments in the manuscript (introductions and initials): since the teratological style prevails in writing since the 13th century [9], then it can be assumed with a high degree of probability that the manuscript was written at the beginning of the 13th century.

The confusion of the letters e, э, и and ), оу and в, the appearance of жч combination, - all these features of the orthography of octoiha confirm the book origin - the southwest of Russia.

\section{Acknowledgements}

The work is performed according to the Russian Government Program of Competitive Growth of Kazan Federal University.

\section{References}


Lyubashchenko V. Religious manuscripts of Halych-Volhynian Rus' of the 12th-14th centuries: an attempt to generalization // Княжа доба: історія i культура, 2011. - № 4. - pp. 65-99.

Hanke von Hankenstein J. A. Recension der ältesten Urkunde der slavischen Kirchengeschichte, Litteratur und Sprache: eines pergamenten Codex aus dem VIII Jh., 1804. - 64 pp.

Turilov A.A. Gankenstein Codex // Orthodox Encyclopedia. - 2005. - V. 10. - pp. 411-412.

Shevelov G. Y. Omega in the Codex Hankenstein // Studia Linguistica Alexsandro Vasilii Issatschenko a Collegis Amicisque oblate, 1978. - pp. 369-386.

Birkfellner G. Codex Hankenstein (Codex Vindobonensis slavicus 37): Neutestamentliche Perikopen, 2006. $445 \mathrm{~s}$.

Birkfellner G. Codex Hankenstein (Codex Vindobonensis slavicus 37): Liturgischer Festkalender für den
Jahreszyklus der unbeweglichen Feste, 2007. $-448 \mathrm{~s}$.

Molkov G.A. Peculiarities of the language and writing of the Pogodinsky Gospel (RNB POGOD 11) // Die Welt der Slaven, 2016. - № 2 (61). - pp. 230253.

Oktoechos mit Supplementen: Sog. Codex Hankensteinianus [Electronic resource] URL: http://data.onb.ac.at/rec/ AL00607334 (reference date: 11.05.2017).

Cherepnin L.V. Russian Paleography. M., 1956. - 616 p.

Voskresensky G.A. Slavic manuscripts stored in foreign libraries: Berlin, Prague, Vienna, Ljubljana, Zagreb and two Belgrade ones. - St. Petersburg: the Printing house of the Imperial Academy of Sciences, 1882. - 58 p.

Zholobov O.F. The corpus of the Old Russian copies of the Paraenesis of Ephraem Syrus. II: RNB, Pogod. 71a // Russian Linguistics, 2009. - Vol. 33. pp. $37-64$ 